\title{
职业高中物理教学存在的问题及对策
}

常五旦

陵川县职业中学校

DOI:10.32629/jief.v2i4.1327

[摘 要] 作为职业高中的物理教师, 面对一批批学习困难的学生, 如何把物理教学搞得有声有色, 为各专业的学习打下坚实的物理学基础, 是每位职高物理教师经常思考和研究的问题。只有全面分析职高物理教学存在的问题, 才能对症下药, 制定切实可行的对策, 努力获得物理 教学质量的全面提高。

[关键词] 职业中学; 物理教学; 问题对策

中图分类号: G633.7 文献标识码：A

作为职业高中的物理教师, 面对一批批学习困难的学生, 如何把物 理教学搞得有声有色, 为各专业的学习打下坚实的物理学基础, 是每位 职高物理教师经常思考和研究的问题。只有全面分析职高物理教学存在 的问题, 才能对症下药, 制定切实可行的对策, 努力获得物理教学质量 的全面提高。

\section{1 职业高中物理教学存在的问题}

1.1 生源质量差, 学生学习困难

职业教育的目的是为社会培养有一技之长的高素质的中等技术人 才, 这对整个中国社会是很必要的, 也是非常重要的。但是人们的观念 还一时未能转变, 总是盯着考大学这一条道。职业中学招生批次靠后, 每年招生都是各类普通高中各自划定分数线后, 剩下的中考分数相对差 的学生, 他们上不了普通高中, 在职高许多优惠政策下才无奈地来到职 业高中。他们中的大多数学生学习成绩差, 学习能力不强, 没有明确的 学习目标, 学习习惯不良, 对学习缺乏信心、兴趣和主观能动性。

\section{2 整体学习风气不良}

有些参与学习的同学往往受到整体学习风气的影响而随波逐流, 放 弃学习。有的学生积极学习, 会受到其他同学的挖苦、讽刺。职业中学 学风不良的原因是多方面的: 一方面来自于社会对职业中学及职业中学 学生的歧视, 还有就是学生家长, 他们因孩子没能考上普高而丧失对孩 子的信心, 有的家长甚至只是让自己的孩子鳌三年时间, 混毕业证。再 就是学生普遍基础差, 遇到困难容易放弃学习。

1.3 物理实验器材短缺

职业教育的发展重在各专业的建设和发展。因此, 职业中学都注重 树立专业品牌, 如建立多个计算机室, 建设了美术基地, 电焊基地, 机 床机房, 机电设施, 往往忽视了专业基础课物理实验的建设。

\section{2 提高职业高中物理教学质量的对策}

\section{1 齐抓共管扭转学习风气}

近年来, 面对职业中学学风不佳的现状, 我校组成了以校长、政教 处、班主任、教官、任课教师、以及宿管员、门卫为责任人的集体组织, 齐抓共管扭转学生学习风气, 取得了很好的成效。学生们确立了自己的 人生目标，生活习惯养好了，上课上自习井井有条。

2.2 用强烈的责任心和爱心感化学生

职高学生普遍学习成绩差, 甚至调皮捣蛋, 不好管理。单靠强制管 理学习是不行的, 教师应用强烈的责任心和爱心去感化学生, 真心和学 生 “交朋友”, 充分了解学生厌学的原因, 从关心爱护学生入手, 通过情 感交流, 打开学生在家长、老师面前久闭的心门, 使其敞开心扉, 真诚 地与老师交流, 从而对症下药, 因材施教, 逐步调动学生的主观能动性, 使学生从思想、行动、习惯等方面逐步转变, 逐步实现由 “他律” 到 “自 律” 的转变, 进而自主学习, 乐于学习。教师要及时发现每个学生的闪 光点, 充分肯定和表扬学生, 尤其是对基础差而又自卑的职高学生来说, 他们更需要得到老师的关注和鼓励, 老师的微笑会消除他们的紧张情绪, 老师的耐心辅导除能解决他们的困难之外, 更能使他们感到温暖。只有 尊重学生, 关爱学生, 越是在学生有困难的时候, 越注意多鼓励、多关 心、多指导, 想方设法使其获得学习成绩有所提高时的成功喜悦, 才能 激发他们的学习兴趣。“亲其师, 信其道。” 教师爱学生, 学生才爱老师, 也才爱老师教的学科, 才能对该学科产生兴趣, 从而主动学习, 逐步改
变多年集聚的不良习惯。

2.3 创新教学思路, 提倡 “低起点, 慢节奏, 低要求” 的教学思想

刚入学的新生对学习物理有一定的新鲜感, 有足够的求知欲, 教师 要充分利用这一时期, 培养学生课前课后阅读教材的习惯。整合教材内 容, 对 “现代通信技术” 等不涉及物理知识而又难以理解的部分删减或 自阅读了解, 减少总授课内容。提倡 “低起点, 慢节奏, 低要求” 的教 学思想, 逐步唤起学生的学习兴趣和自信心。低起点, 就是每个单元起 点知识都要充分把初中知识和高中知识衔接好, 在讲解、复习初中知识 的基础上实现向高中教材的自然过渡, 教学中力求知识点之间实现有效 对接, 知识之间逻辑联系紧密, 台阶小, 知识跨度小, 学习过程中遇到 的挫折和困难相对较少, 学生容易掌握, 容易成功。慢节奏, 就是放慢 “教” 与 “学” 的速度, 使学生学练结合, 在学与练中掌握知识。每次授 课内容要少, 效果不佳时重讲, 不急功求利, 不贪多。低要求, 就是降 低评价标准, 不能总拿完美答案要求学生, 充分肯定学生每一点进步, 使学生学有所得, 感觉到自己的每一次跳跃都能摘到桃子, 从而培养学 生的成就感。

2.4 充分发挥多媒体的作用

电磁学是比较抽象的一部分内容, 教学中, 往往很多情况是难以想 象的。但多媒体可以帮我们这个忙, 它把抽象的东西变得具体、形象、 一目了然。有些演示实验具有可操作性, 但实验过程变化快, 变化小, 不容易观察。在多媒体上可以把想象放大, 更容易接受。多播放一些物 理学家的故事, 紧紧地吸引学生的注意力, 让学生们了解物理学家们孜 孜不倦, 持之以恒的探索精神, 鼓励学生养成良好的品格, 不仅应具有 过硬的物理技能, 还要有宽以待人, 吃苦耐劳的品格。还可以播放一些 与课堂有关的现代科学技术成就, 不仅开拓了学生的视野, 也是很好的 爱国主义教材。

\section{5 联系实际理解物理知识}

首先, 利用现有的物理实验器材做好演示实验, 并鼓励学生自己动 手, 要求学生通过自己的动手或者合作的形式来完成实验, 在这个过程 中, 可以培养学生的观察力, 动手能力, 思维能力等。其次, 积极制作 教具。例如: 合力与分力关系的平行四边形 “活动架”; 电路分析所用 “电 路板” 等。每次利用这些教具讲解, 学生更觉形象、具体。再者, 物理 学是一门自然科学, 生活中无处不有物理现象存在, 只是人们熟视无睹 罢了。所以, 要学好物理知识, 还应引导学生善于观察事物, 善于利用 自己所学的物理知识去解释事物。在物理教学中, 常把各专业与物理有 关的现象拿到课堂上研究。例如: 电工人员常遇到的一个问题: “灯泡不 亮, 用数字电笔测灯口两端都显示 $220 \mathrm{~V}$, 问故障范围。” 经学生分析, 讨论, 利用所学电学知识, 最后, 学生答出 “零线断路” 的正确结论。

\section{[参考文献]}

[1]郑素侠.关于高中物理教学中创新能力的培养[J]. 数理化解题研 究,2020(24):38-39.

[2]刘广平.高中物理教学中能量与做功的对应关系分析[J].数理化 解题研究,2020(24):43-44.

[3]陈静珠. 深度学习视角下高中物理优化策略 [J]. 试题与研 究,2020(24):102. 